\title{
Exploring Experience at the Intersection of Migration and Digital Democracy in South Korea
}

\author{
Iris Lim \\ soAs, University of London, London, UK \\ il8@soas.ac.uk
}

\begin{abstract}
This article examines how digital spaces for political participation by migrants are experienced and governed in South Korea. Drawing on semi-structured interviews conducted in Seoul, South Korea, between April and July 2018, this article argues that migrant participation in digital democratic processes in South Korea is hindered by a fragmented and centralized digital management, which can be linked back to the specific historical-political context in which this digital space was developed.
\end{abstract}

\section{Keywords}

digital democracy - immigrants and e-government - Korean migrants

\section{$1 \quad$ Introduction}

In the spring of 2020, as countries around the world went into their first round of lockdowns due to the COVID-19 pandemic, South Korea (hereafter, Korea) made international headlines with reports widely praising the country's use of digital technologies to contain the spread of the virus without resorting to a severe lockdown (Ahn 2020; Cellan-Jones 2020). The Brookings Institution reported that 'Korea's ability to quickly repurpose and integrate different forms of digital information [during the pandemic] is a testament ... to existing infrastructure and procedures' (Fendos 2020: para. 9).

This event is a recent example of Korea's expertise in digital government and highlights Korea's significant investment in information and communications 
technology (ICT) over the past seven decades, especially with the growth of widespread internet connectivity since the 199os. ${ }^{1}$ Korea has one of the highest rates of internet connectivity in the world, with 96 percent of the population accessing the internet daily as of 2019 (World Bank 2019), and the government has been quick to incorporate digital ICT into its remit. Since 2005, Korea has ranked in the top five e-government systems in the world, in first place from 2010 to 2014 and second in the 2020 overall e-government rankings (UNDESA 2020a).

The sophistication and prominence of digital government infrastructure in Korea is well documented (Chung \& Kim 2019; Karippacheril et al. 2016; UNDESA 2020b). However, as the literature moves beyond macro-level analyses that examine Korea's digital government systems at the national level and towards micro-level considerations of how individuals or communities experience these systems, we can see that a variety of social, political, and cultural dynamics with respect to the country's digital systems have yet to be explored. One such area is the way in which Korea has increasingly become a destination country for migrants and the interaction of these demographic changes with the country's digital government systems.

Alongside the rise of digital ICT and rapid neoliberal globalization in the 199os, the prominence of migration into the country has also grown. Since 2005, net positive migration to Korea has averaged 71,00o per year (КОSTAT 2019), with an increase in documented migrant residents of 26 percent between 2003 and 2019 (Korea Immigration Service 2019).

In the context of these impressive parallel changes, some interesting questions arise at the intersection between the proliferation of digital communication technologies in the country and the social, political, and economic metamorphoses that result from increases in human mobility. Of particular interest is that the growing migrant population poses a variety of new considerations and challenges many assumptions with regard to political participation and digital democracy. How are migrants included and/or excluded from participation in Korea's digital government systems? How are these practices experienced? And what determines the space allowed for migrant voices and participation in the development of digital government platforms?

The field of literature that considers how digital technologies shape the democratic landscape in Korea (Gibson et al. 2004; Karippacheril et al. 2016; R. Kim 2019; Sangki 2018) has paid little attention to Korea's migrants and their experiences of these changes (see Aricat 2015; Garcia-Garcia \& Gil-Garcia 2018 for examples of such research in different contexts). Considering the rapidly

1 This article alternates between the terms 'digital government' and 'electronic government' or 'e-government', as is common in the literature. 
growing prominence of migrants in the country, this is a significant gap in the literature, which this article aims to address. It contributes to our understanding of these broader questions by considering how an examination of individual experiences with digital government can add to a broader view of digital government and democracy in Korea and the Asia-Pacific region.

\section{$2 \quad$ Methodology and Research Questions}

A methodology that captures individual experiences with digital government, while connecting individuals to the wider institutional order and social relationships that shape these changes, is needed to unpack existing assumptions about these experiences at the intersection of two parallel social shifts in Korea: the rapidly growing migrant population and the extensive shift to digital government (Smith 2005, xii). How do people understand their relationship to government while navigating these digital government websites and services? How does this make them feel about the digital technologies as well as the wider communities to which they belong? Our research to explore these aspects of digital government experiences is inspired by the institutional ethnography of Dorothy Smith (2005) and the work of Star and Ruhleder (1996), which views digital infrastructure as inherently relational and determined by the positionality and perspective of those who are viewing it.

In taking this approach to contextualizing the intersection of digital government and migration in Korea, this article uses data from fieldwork conducted in Seoul, South Korea, from April to July 2018, involving interviews and observations of migrant and non-migrant users of digital government services and the managers and gatekeepers of those government websites. A wider multimonth and multi-sited comparative study of migrant experiences with digital government conducted between October 2017 and December 2019 supplements this evidence.

This article seeks to address the following questions:

- What are the characteristics of the historical and political context of digital government that inform the nature of digital democracy in Korea?

- What are some of the ways in which these characteristics inform and influence how digital government and, in turn, digital democracy, is experienced by migrants?

In addressing these questions, I first introduce the necessary concepts and historical background, highlighting key concepts about the digital divide and political participation. Then, I present a brief historical overview of the development of digital government in Korea, followed by the specifics of my case study. This section draws out the executive branch-driven, top-down nature of 
digital government systems in Korea resulting from Korea's unique historicalpolitical context of the early 199os, with the late democratization and the rapid neoliberalization that was a part of its development trajectory which can traced to this time. I consider how this context influences the current practices of inclusion and/or exclusion of migrants from aspects of the country's e-government systems and how that shapes the experiences of governmental and non-governmental digital practices for political participation in determining the quality of digital democracy in Korea.

Next, I provide some concrete examples from my fieldwork to explore the people's experiences of a selection of digital government websites, including the following categories of participants: (1) migrant users, (2) non-migrant users, (3) managers of digital government platforms, (4) non-governmental community activists, and (5) migrant community activists. These categories are not definitive and exhaustive, and the experience of these participants might not apply to everyone in their category. However, these excerpts offer valuable insights for understanding some of the reasoning and motivations that drive the experience of digital political participation in Korea and is a useful precursor to a more systematic analysis. Lastly, I consider some of the lessons learned.

Through this empirical exploration, I consider how Korea's historicalpolitical context creates digital government practices that perpetuate barriers to the inclusion of migrant in both use and participation in the process of their development. The participants interviewed and observed in this research evidence the historically developed top-down, executive branch-driven nature of Korea's digital government systems. These interviews demonstrate that the lack of communication between government bodies created a segmented digital system that migrants find hard to navigate, not only limiting access to digital space but perpetuating a sense of apathy amongst migrant populations about use and involvement with the development of digital government systems. As such, this research observes that migrant participation in digital government is hindered not only by digital government's functional dynamics and practices but also by how these practices intersect with the wider historical and political contexts of how a state's ICT policies and systems developed.

Digital democracy (sometimes referred to as 'virtual democracy', 'e-democracy', or 'cyber democracy') is broadly defined as the use of ICT in engaging in democratic practices and enhancing democratic participation (Hacker \& van Dijk 
200o; Zúñiga et al. 2010). It is a concept that explains a wide range of policies and practices. When we think about digital democracy, some topics and examples that initially come to mind are electronic voting (Kersting \& Baldersheim 2004), comments and forum-based public consultations (Janssen \& Kies 2005), social media and political mobilization (Boulianne et al. 2020), and data availability and transparency of government debates and accounts (Bertot et al. 2010; S. Kim \& Lee 2012). How do these practices and policies connect within digital democracy, and what does the literature say about them?

The intersection of digital technology and democracy is an area of research with a well-established literature, so we have many ways of organizing and thinking about it. The following literature review covers a selection of this existing literature, providing a brief overview of scholarship examining the relationship between digital technology and government, as it shifted, broadly speaking, from technology-centred explorations to a more socially embedded understanding.

\section{From Potential to Contextualization of Digital Government and Democracy}

Although the literature on digital democracy and digital government can be framed in many ways, the research has progressed from exploring the potential of digital technologies for government, to investigating the implementation of ICT in government, to unpacking assumptions and drawing contextual nuances in the unfolding relationship between ICT, governance, and society in the course of this implementation.

In the early 200os, researchers focused on the potential of digital technologies to improve the quality and breadth of democratic engagement, making it easier for citizens to vote, communicate with their representatives and wider community, and mobilize (Gibson et al. 2004). This literature was connected to explorations of the application of digital methods to a variety of government functions, exploring the definition of e-government (Silcock 2001), recommendations of a 'stages of growth' model for facilitating e-government initiatives during implementation (Layne \& Lee 2001; Warkentin et al. 2002), and thinking about how ICT can be used in specific government functions such as local government administration (Ho 2002) and counter-terrorism measures (Halchin 2002). Explicit explorations of digital democracy at this early stage were relatively rare. However, early explorations by Kenneth Hacker and Jan van Dijk (2000) articulated initial definitions of digital democracy and examined digital government initiatives within the framework of democracy. 
Research on digital government rapidly increased in the mid-20oos to match the growing scale and breadth of implementations of digital government. This was encouraged by the international attention paid by surveys, such as the UN E-government Survey, which ranked the ways in which ICT was applied in various government practices across different countries. Digital government scholarship also became increasing differentiated by discipline, at first limited to studies of information systems, management, and organization (Iyer et al. 2006; Loukis et al. 2005) and then extending to research on politics and public administration, examining the context of the communication between the government and citizens, with more explicit explorations of digital democracy (Hacker \& van Dijk 200o; van Dijk 2000; Warkentin et al. 2002). Although much of the literature at this stage did not sufficiently ponder the wider social implications of implementation, the differentiation into different disciplines helped to move the focus in studies on digital technologies and government from the realm of technology to that of the social sciences.

Current studies have continued to explore the implementation of digital government in a variety of contexts, flipping the focus from implementation of digital ICT as a 'solution' to that of the increasing diversity of contexts in which implementation occurs, with attendant digital changes. This shift demonstrates that, despite the tendency towards 'technological solutionism' in the practice and study of digital ICT in relation to governance and democracy, especially when new technologies are applied (i.e. mobile, broadband, etc.), the earlier assumptions are being re-evaluated, as we develop a more socially embedded understanding.

The literature on this topic is so voluminous that it would be impossible to cover it all, however, the following offers a selection of some of the key tensions, distinctions, and findings in it. The first is a shift driven by the increasing global spread of digital government technologies to non-Western contexts, such as the Asia-Pacific, which test previous findings and claims and illustrate the expansion in our understanding of digital democracy that comes from having multiple perspectives. As digital ICT was implemented in different contexts, nuances began to emerge in how to view the dynamics of governance, people, and technology. For example, research in diaspora media studies, such as Victoria Bernal's (2006) work on the Eritrean diaspora's digital engagement finds that web postings by the diaspora regarding Eritrean government and politics rearticulate and reconstruct community values, shaping political practices and new forms of transnational citizenship. S.B. Kim (2019) has written about the political engagement of social media users in Korea, finding that active use of social media is significantly associated with offline voting activity. 
In addition to the contextual expansion, an expansion in interdisciplinary approaches occurred. Management studies examined the impact of different models of e-government websites, such as the trend towards 'one-stop shop' government websites and an interest in citizen satisfaction and transparency (Knox \& Janenova 2019). Sociologists advanced views of the digital divide through the lens of social theories, such as Bourdieu's habitus, to examine systemic political and socio-economic disadvantages in Atlanta, Georgia (Kvasny \& Keil 2006). Media studies developed perspectives on different types of internet use (van Deursen \& van Dijk 2014).

Another development emerging in the literature at this time was the questioning of assumptions made in earlier papers regarding claims of the internet's power for the mobilization of political participation and found that this was not true in all cases. Fadi Hizralla's (2011) research on different age groups in the 2006 Dutch parliamentary elections found that the internet's political mobilization power was age dependant. Additionally, in their work examining growing apathy and declining civic engagement among youth, adding the relationship between online and offline interactions, Shakuntala Banaji and David Buckingham found that although young people extolled the utility of internet communications for political engagement, political participation and mobilization 'still began and ended offline, the internet sustaining and contributing to offline activism' (Banaji \& Buckingham 2013: 16o). Because of the efforts made to broaden electronic government and every new technology introduced or context examined, the literature in this contextualization stage critiques the influence of these new technological developments on governance systems and wider governance processes.

\section{5}

\section{Classes of Technology, Digital Divide, and Digital Democracy}

Another key dynamic that emerged and evolved during this stage of the literature is the exploration of how different social, economic, and political dynamics result in potential barriers to the successful implementation of digital technologies for political engagement. This concept, the digital divide, has existed for as long as we have had digital communications technologies. However, it has grown in complexity with the technologies and development of socio-technical research. At first, it was framed a simple issue of access to the technology (Ebbers et al. 2016), resulting in investment in the provision of hardware and software focused on the material aspects of the divide. This effort led to initiatives and research such as the One-Laptop-Per-Child Project 
(Kraemer et al. 2009), which sought to provide laptops for every child in the global south, research on home computer ownership by Latinx students in Texas (Jennings 200o), and tax incentives in the billions for businesses that donate computers and ICT services to low-income schools and communities (Attewell 2001). Yet even though the physical technology became more readily available, the gap continued to exist.

Over time, the concept of a 'digital divide' has developed into an understanding that considers not just resource gaps and skill gaps but an ever-growing list of social divides, including factors such as age, race, culture, and gender. Therefore, the literature has tried to achieve an understanding of the digital divide that is more socially based, so the reasons for the persistence of the digital divide have been extended to consider social, cultural, and economic inclusion and exclusions. The most current definition defines the digital divide as 'the gap between individuals, households, businesses and geographic areas at different socio-economic levels with regard both to their opportunities to access ICT $s$ and to their use of the internet for a wide variety of activities' (OECD 2002). Therefore, the digital divide is now understood as both an expression of other forms of inequality, including social and economic, and as the perpetrator of them.

Efforts to address this 'digital divide', led by international organizations and governments around the world, are characterized by the provision of access to technologies (in the form of multimedia centres, laptop computers, mobile phones, tablets) and additional resources to enable people to make sense of it, such as technical skills. For example, the Korean government funds classes for senior citizens to learn how to use smartphones tailored for their daily lives (ABC News 2019). However, these measures still fall short when we consider who is included in the Korean government's digital inclusion initiatives and who is not. For example, during my fieldwork, I observed that government skills classes for oegugin (foreigners), which included digital skills classes, were much more visibly offered through pamphlets and flyers at Multicultural Family Centres and universities than at community spaces for temporary migrant workers, even though many of them remain in the country much longer than those on student visas (fieldnotes, 10 June 2018). ${ }^{2}$

Scholars argue that digital divides - whether spatial, socio-economic, or material (Ramalingam \& Hernandez 2016: 68) - can both reflect and perpetuate existing social and economic disparities. Given that internet and mobile infrastructure is disproportionately concentrated in areas

2 Data from fieldwork is referenced with the date that it was collected and indicating the type of data. 
with the most buying power, disparities in ICT infrastructure often reflect economic disparities, social disparities (e.g. race and gender divisions), and geographic disparities (e.g. the rural-urban divide). For example, people in urban areas are more likely to be connected than people in rural areas, and urban areas often have divides between affluent centres and inner-city neighbourhoods (McKinsey 2019). Moreover, government surveys used to inform policies on digital inclusion are not sensitive to gender division with regard to their digital poverty targets, as demonstrated by a study on digital poverty in multicultural families in Korea (Lee et al. 2016).

Digital divide distinctions are also made between device types. Most new users now get their first taste of the internet on mobile phones. Smartphones are increasingly faster and have many functions but are less suitable than desktops and laptop computers for performing some complex tasks. 'Digital by default' and mobile-only approaches risk leaving behind those who are the most marginalized (Al-Muwil et al. 2019). These points all demonstrate that the digital divide is not just about economics. Evidence shows that digital divides exist in the dimensions of ethnicity, gender, education level, caste, disability, and age (Goggin 2016; Rowsell et al. 2017).

But what does this divide mean for digital democracy and participation? This question is raised by researchers in this new, more socially based understanding of the digital divide, highlighting the need to examine how social barriers can affect access to digital spaces and, in turn, digital participation and engagement. For example, in examining these 'second-level digital divides' that deal with motivations and opportunities for internet use, Seong-Jae Min (2010) discusses the 'democratic divide' as a type of digital divide that considers the level of internet literacy and political interest as motivations for public engagement online.

These concepts of digital government and types of digital divides play a significant role in how democracy functions in Asian-Pacific countries. The socio-economic diversity in the Asian-Pacific region leads to a high level of disparity in Іст access and infrastructure there. This regional digital divide is particularly prominent between Japan and the four 'Asian tigers' (one of which is Korea), on the one hand, and the other countries in the region, on the other. In Korea, 95.9 percent of the population uses the internet (Asia Internet Stats by Country and 2019 Population Statistics 2019), with the biggest recent increase in internet use among the elderly, from 6o to 69 years old, increasing the rate of internet use among them from 41.8 percent in 2013 to 82.5 percent in 2017 (Korea Internet \& Security Agency 2017). However, these impressive numbers look less than rosy after they are unpacked. 
Migration is a key dynamic mentioned by the United Nations in an itemized list of digital divides. The divide in migration is described as due to the fact that 'migrants may not possess the same levels of digital skills as the population in their new country and if they do, may be subject to content and language divides' (UN 2018: 34). As we now see that the digital divide is much more complex than we once thought, consideration of hardware and infrastructure, although important, are not the only factors worth noting. What also matters is the degree to which the technology is available and the ease with which migrants can use it in their everyday activities.

Instead of having a neat division in use between owners and non-owners of technology, what has emerged is evidence of distinct social stratification in technology use and access that mirror socio-economic divisions. For example, Hernandez and Roberts (2018) devised classes of technology access related to dimensions of ICT class divisions based on employment, devices, and connectivity and arrived at variations in technology experience. The classes of connectivity range from a 'digital underclass', which is disconnected by default because of limited airtime and no mobile data, to a 'digital upper class', which enjoys the latest iPhone, unlimited mobile data, and wi-fi at home and at work. Between these extremes are classes with intermediate levels of access and connectivity (Hernandez \& Roberts 2018: 10).

These 'classes of technology' were readily apparent in my field observations in Korea, while people were gathering to protest in support of migrant labourers at the Ministry of Labour. Migrant protesters could be seen huddled together with organizers as they figured out how to share data with other workers who were on their way to the protest and conserve on their data usage (fieldnotes, 14 June 2018). Even though both the migrant protesters and nonmigrant protesters both had access to mobile data and could be counted as such in statistics on national connectivity, the quality and usability of that connection demonstrates digital divides in terms of who has more accessible, comfortable, and consistent access to digital services. This is one example showing that even in a country with the highest internet use statistics in the world, the data demonstrating aspects of digital usage are still unclear regarding details on quality and usability of these digital engagements.

\section{Historical-Political Context of ICT Development in Korea}

Next, we explore how digital government and democracy take shape within the historical-political context of Korea. This section covers how Korea's digital transformation became a part of the nation's quest for modernity and 
development as a part of the country's intensifying neoliberalization after the 1997 International Monetary Fund (IMF) debt crisis and restructuring of its government policies. The following section looks at how this historical-political context gave birth to Korea's current digital government systems and informs digital government experiences, with a particular focus on migrants. Although we can trace the history of modern communications policies in Korea back to the electronics and telecommunications developments in the 1920s, this history starts in the 199os, when internet use began to spread in earnest. This history is described along with increases in migration that also occurred during this time, showing that digital government policies and migrant policies in Korea are both pushed by top-down, centralized initiatives driven by the administration in power.

\section{$7 \quad$ Korea's Globalization and the Establishment of Digital Government}

The transition from dictatorship and civil unrest in the 1980s, rapid economic development, and the opening of the country in 1988 during the Seoul Olympics, set the stage for a memorable 1992 presidential election that brought the first civilian president to power in the country, Kim Young Sam. In this new civilian administration, segyehwa (globalization) was first articulated by Kim in the mid-199os, launching a

discourse of Global Korea [that] was not merely a point of departure in Korean diplomatic practice but was also a key site of Korean national identity construction, as manifest in the discourse of achieving seonjinguk (advanced nation) status through development. However, in the context of globalization, the scope of the discourse of seonjinguk has been expanded on the pretext of meeting a 'global-standard' in every aspect of Korean public life.

JOHN 2016: 40

Transitioning away from the failures of the previous dictatorship of the Chun Doo Hwan administration, the Kim presidency embraced globalization as a new development goal pushed by the Korean state that sought to achieve 'advanced nation' status by meeting a certain internationally set criteria.

Under Kim, Korea became an early investor in e-government as a result of direct executive branch reforms, with the centralized executive branch order driving the changes. In 1993, an initial plan for the internet information 
super-highway was announced, and infrastructure plans, funding commitments, and governing bodies for governmental digital ICT developments were established in and around 1994. Also in 1994, the Ministry of Information and Communication (MIC) was established, and, in 1995, the National Assembly enacted the 'Framework on Information Promotion Act', which provided the foundation for the 'Informatization Promotion Fund' firmly establishing the fact that funding e-government initiatives had become a priority. In 1996, Kim held the first conference on the executive branch's promotion of e-government, releasing the 'Informatization Strategy for Strengthening National Competitiveness' report.

The end of Kim's presidency came as Korea experienced its worst crisis since the Korean War: the 1997 Asian financial crisis, referred to by many Koreans simply as the 'IMF'. Kim was blamed in part for the crisis after accepting a $\$ 58$ billion bailout from the IMF, to be replaced by Kim Dae Jung, Korea's first 'Liberal' opposition party candidate to win office (Choe 2015). However, in many ways, the 1997 financial crisis furthered Korea's neoliberalization, as some of the structural adjustment policies that were stipulations of the loans that Korea received to bail the country out of its financial problems meant implementing further reforms (Lee 2016). Under the supposed pro-labour administrations of the first liberal presidencies of Kim Dae Jung and his successor, Roh Moo Hyun, the government workforce was downsized as part of streamlining the government and the bureaucracy (Robinson 2007). This effectively extended globalization from the realm of economics and foreign policy to reforms of the domestic public sector.

In 1998, Kim Dae Jung's administration launched the government's official website. Reported as an 'administrative revolution' (Won 2002) by the his government, it promised that 'all government activities will be carried out with transparency in the home of the people' (ibid.). The homepage gave people access to internet-based public services, such as tax filing and real estate registration. In the following year, in consultation with researchers and public opinion surveys, the government created a comprehensive e-government plan and integrated public information and data access system.

These digital government initiatives were continued by subsequent administrations (Kim \& Joshi 2016). The Promotion of Digitalization of Administrative Work for E-Government Realization Act, implemented in 2001, intended to perform all government services on the internet in the name of transparency and better access to services (ibid.). For example, 21 selected key services, such as resident, family, and automobile registration, are integrated across national, regional, and city-level digital services (CPI 2016). This early full-scale adoption 
of e-government and steady development made Korea's e-government regime one of the broadest and best established in the world, especially in terms of online services provision (OSI), in which the country particularly excels (UNDESA 2O2Ob: 12).

These executive branch initiatives for the promotion of digital government have layered motivations. Like many governments experiencing the transformation due to globalization and pressures for restructuring due to the Asian financial crisis in the 199os, the Korean government needed to change its approach to governance (Jho 2014). Therefore, neoliberal restructuring required the economy to be administered through the 'coordination, steering, and regulation' (Jho 2014: 19) of governance in the country. However, rather than digital government encouraging decentralization and transparency, as supposed by neoliberal good governance restructuring, the digital government that emerged in the 199os and 2ooos was a new way of exercising state power and shaped the institutional response to rapid changes in the environment surrounding the Korean state at this time.

\section{Rising Prominence of Migration}

These decades of rapid globalization were also a time when Korea experienced a transition from being a country of emigration to one of immigration, as demonstrated by the statistics on the temporary emigration of Korean laborers. In 1983, emigration peaked at 434,200 workers leaving for jobs in other countries, but decreased to 18,0oo a decade later (Dewind et al. 2012). The rising prominence of migration to Korea came in 1995, when thirteen Nepalese migrant workers staged a sit-in in front of Myeongdong Cathedral to demand 'minimum wages, industrial accident compensation, eight-hour day, and other protections' (Lee 2014) given to Korean workers under the country's labour laws. This sit-in, which was the first widely covered migrant protest in Korea and led to satisfaction of the demands of the Nepalese migrant workers, marked the beginning of a new awareness about the existence and issues of foreign migrants within the country (ibid.). More than twenty years later, the Korea Immigration Service in 2019, the number of 'foreigners', the category given to all non-Koreans, residents in Korea numbered 2.07 million.

This new awareness and prominence of migrants led the government to make a two-part effort to manage migration to the country. The first was the building of an official migration policy. The country created Korea's First Basic Plan for Immigration Policy in 2008, as the first of a series of policy acts, such 
as the Nationality Act, Immigration Control Act, and the Framework Act on the Treatment of Foreigners, which focused on controlling and managing immigration (Chung \& Kim 2012). This formalization of the immigration process allowed greater transparency to prevent the incorporation of migrant issues into the strong labour rights activism in the country, but at the same time, the number of deportations and the policing of immigration increased from this point on (ibid.).

During this institutionalization of migration management, migrants in Korea were categorized according to their type of migration path. The main categories, in terms of the type of visa obtained by migrants, were migrants (mainly from Southeast Asia, China, and the Philippines) who were getting married; temporary labour migrants (mainly from South and Southeast Asia); foreign students; and white-collar migrants. These categories reflect an emerging racial stratification and colourism in the varying treatment of migrants and the subsequent levels of inclusion in and exclusion from society (Kim 2020).

Second, in response to the social issues created by the increasing number of foreigners and multicultural families that were produced due to the rise in labour and marriage migrants over time, the government actively encouraged the rhetoric of a 'multicultural Korea' (Chung 2010). However, although this progressive, migrant-positive rhetoric could indicate of a more tolerant attitude by the Korean government, relative to neighbouring countries (Chung 2010; Chung \& Kim 2012), some scholarship suggests otherwise. Han Jin Eom (2008) suggests that the active encouragement of the multiculturalism rhetoric is just a part of the overall development rhetoric of 'Global Korea', an effort to give the appearance of having met a certain international standard of development that is not reflective of general social attitudes. An ethnography of schoolchildren conducted by Yoon Shik Kim (2009) finds that the identity of multiculturalism was not always embraced by migrants and their children in Korea, as it had a negative connotation. Additionally, Sookyung Kim (2015) characterizes immigration control and rhetoric as shaped by a process of 'decoupling', in which migrant-positive 'soft rhetoric' is contradicted by 'tough actions' and the implementation of exclusionary and assimilation policies.

These studies show that, rather than allowing multiculturalism to emerge naturally from an actual integration of migrant populations in the society, 'Multicultural Korea' was a government-led, top-down initiative to control the social 'growing pains' caused by demographic changes and in response to domestic and international pressure to institutionalize protective measures for migrant workers (Kim 2014). 


\section{Perspectives on the Contemporary Dynamics of Digital Democracy} in South Korea

So, what does this historical-political context of globalisation under a centrally driven, top-down policy regime mean for the experience of migrants with digital government? How does this inform digital democratic engagement? The following section explores some of these considerations by incorporating a selection of data from 54 semi-structured interviews and approximately 375 hours of field observations from my fieldwork to flesh out this case study.

The early developments in digital government in Korea described earlier demonstrate strong government support for exploring the potential for using ICTs in the delivery of public services, with investment planned for it. The impetus for this digital shift can be understood as a push by the central government administration, which is reflected in how users experienced digital government. This centralized approach had positives and negatives in terms of how the public accesses and engages with public services, as discussed below.

Although all e-government systems include spending considerations, my research data did not reveal cost-cutting as a prominent topic related to e-government. Cost-cutting as a driver of e-government development was not mentioned unless it was prompted in the five semi-structured interviews conducted with digital government managers in Korea, and even then, the focus was more on national competitiveness and development in the country (observations, 21 July 2018). This is not surprising, as this is mirrored in the government's promotion of e-government. In 2002, under President Roh Moo Hyun's Participatory Government, e-government policies were geared towards the promotion of 'informatization', meaning efficient information access. In May 2003, the administration released its 'Participatory Government's Vision and Direction of E-government', followed in August by its vision for creating the 'World's Best Open E-government'. This detailed a plan to increase available online public services by 85 percent and the use of e-government programmes by 6o percent. This 'Participatory Vision' turned into Minwon24 (www.minwon.go.kr), which is the main government-to-consumer online portal for accessing government services.

Minwon24 (The People's 24), called a 'One Touch, One Government' system, is designed to provide consumers with digital government services, information, and communications $24 / 7$ at the touch of a button. As described on the webpage 'About the GOV.KR' (Gov.KR, 2020), the system is described as a platform that 'consolidates 70,0oo different types of government services available to the public and classifies them into 12 categories.... [It] provides customized 
services in a variety of ways that are tailored to each individual citizen's life'. Consumers can use it to 'check support services and benefits that are customized to serve different stages of your life (infants, children, young people, etc.) as well as the different characteristics (disabled, low-income, multicultural, etc.) of your life' (ibid.).

A couple of things are interesting to consider here. First, in view of Korea's developmental efforts under international pressure for neoliberal globalization, it makes sense that the promotion of Korea's e-government system is driven by considerations of the country's international position and promotion. In some ways, the development by the administration of e-government was a way to declare, to Koreans and a world audience, that Korea is a modern nation plugged into the dynamics of globalization. As such, in some ways, Korea's e-government is not just for Koreans. In 2015, it was reported that Korea's e-government system has been exported to countries seeking to implement such systems of their own, generating USD 314.42 million in revenue in just the first half of that year (Limb 2015).

This focus becomes apparent from the feedback on the website's design and implementation. An interview with a manager of the Seoul e-government system demonstrates that the website design and user experience considered two audiences:

We get feedback from citizens ... we do a lot of focus groups and surveys with them. We also get a lot of feedback from different countries that we export our systems to.... it's nice to see that the systems we design are used abroad, and it makes me proud to know that. (Interview, 16 July 2018)

None of the interviewees in any of the semi-structured interviews I conducted with managers and developers of Korean government websites mentioned considerations of migrant users of the websites until they were prompted.

This is not to say that Korea's e-government websites have no content for migrants, and as digital government has expanded, it has added functionality for the management of migration and migrants, which has become a prominent and growing part of Korea's e-government. Currently, more than fifteen government websites are devoted to migrants, including portals to apply for temporary work visas, websites for international students to access support and services, and access to integration programmes for marital migrants. However, this increase in the number of websites devoted to services for migrants did not necessarily enable service needs to be met or reduce barriers to access, 
as they were not designed with a migrant user in mind. Saif, an international student pursuing a $\mathrm{PhD}$ in artificial intelligence, said in an interview:

The websites aren't very intuitive. I help a lot of people from Pakistan living in Korea and have been on these websites often and even I have hard time with it. Maybe it's the weird, official language used? The way the information is set-up? (Interview, 25 April 2018)

There seemed to be increased awareness of migrants as a part of the population using the internet in Korea, but the digital fluency of migrants was always discussed relative to the skill level of Koreans. Throughout my fieldwork, comments like the following were expressed repeatedly in my conversations with Koreans in Korea. Lee, a community organizer, commented at the start of my research:

Well, these days, in Korea, everyone is using the internet. Everyone is a netizen, speaking out about all sorts of things. Even old people have smartphones and are online. I get my parents a new mobile phone pretty much every year. We are in the internet age. (Interview, 22 May 2018)

Although he did not mention migrants, when prompted about oegugins (foreigners) living in Korea, he said:

Well, even they all have phones now, too. All of them have smartphones, and they message with their families back home. (Interview, 22 May 2018)

This conversation with Lee raises two issues. The first is the suggested connection between being Korean and being a netizen. As of 2019, Korea's internet penetration was one of the highest in the world, with 96.2 percent of its population using the internet (Statista 2021c). For comparison, Japan's internet penetration in 2019 was 93 percent and the regional average for global penetration in Eastern Asia was 70.6 percent as of April 2021 (Statista 2021a; Statista 2021b). Moreover, among those with a connection, almost 99 percent use the internet once a week (Ramirez 2017). These statistics when divided into age groups are also intriguing. In the age group from the teens to the fifties, it is not surprising that Korea had nearly 100 percent internet use considering the nearly complete penetration (ibid.). Even among senior citizens (those age sixty and up), more than 70 percent were online (ibid.). 
The netizen label suggests a high level of online engagement, suggesting the consistent use of complex technical skills, such as navigating social media platforms and a constant online presence. It also suggests an element of community and political engagement. Some efforts are made to engage and encourage senior citizens as well, with community centres offering them government-sponsored social media classes (observations, 22 May 2018).

However, in contrast to the efforts to support increasing internet use by seniors, no equivalent digital inclusion provisions have been made for migrants. Most digital inclusion classes take the form of computer literacy classes as a part of overall migrant integration services. However, eligibility for access to these classes is limited, with different types of classes available for migrant workers and for marital migrants (observations, 22 May 2018). Government-sponsored computer literacy classes are given by an instructor in a classroom, covering only basic computer skills without any instruction on social media engagement and new forms of ICT. An employee at one of the many multicultural family support centres throughout Seoul stated:

We help migrants so that they can learn basic computer skills and so they can access and navigate the internet, which is a big part of living here. (Interview, 28 May 2018)

However, this scope is too limited for what migrants want and need to be able to develop deeper engagement online. When asked if she ever took a computer literacy class at her local migrant support centre, Maria, a marriage migrant from the Philippines, said:

I've never taken them. They don't really help me. I'm fine with using the computer basically, and it is the only thing it covers. I don't find it very helpful. I ask for other kinds of classes, but they are never offered. Only basic things. (Interview, 14 June 2018)

This selection of comments shows a disconnect between what is offered by the government programmes and the requirements for access to deeper engagement online, which is needed for political participation online. This is problematic if part of 'being Korean' is defined as digital participation. Those who are unable to cross the digital divide are framed as outside the community, so this divide extends beyond digital technologies, separating migrants from involvement in the social exchange that is part of political participation in Korea. 
In his book on digital nationalism, Florian Schneider (2018: 21) states that:

the use of technology takes place in a political and economic environment that precludes specific choices. There are rules, for instance, that govern the purposes for which knives should or should not be used. Stabbing others is punished by modern societies, at least outside of specifically sanctioned interactions such as wars. Similarly, what kinds of knives can be made or owned is regulated. Double-edged knives or knives with retracting blades are prohibited in many places. Then, there are the economic dynamics that make producing specific technologies and designs more attractive than others.... These factors may, at times, be complex and hard to trace, but they shape technological uses nonetheless.

The use of digital technology does not occur in a vacuum. Digital technology exists and is used within specific socio-political contexts which preclude certain choices or actions, such as that the ease of access and social connections beyond the functional aspects of the technology influence how people engage with e-government systems.

In this article, we explored how Korea's unique historical and political contexts influenced the creation of a centralized digital government system, in which cordons off spaces of digital political participation from migrant users and results in a centralized system that makes it hard for migrants and their opinions to be heard and fed back into the user-experience development of digital government websites. This makes it harder for migrants to access digital government systems and spaces to contribute to the political discussion and participate in them in meaningful ways.

Although it is hard to say what the degree of the impact is of each of these elements in exacerbating the 'democratic divide' (Min 2010) for migrant users from the empirical explorations in this article, we can ascertain from the historical overview and interviews that these wider political and structural contexts play a role. The qualitative glimpses provided in this article point to the need for more nuanced and detailed research on each of these dimensions. Future research could combine quantitative data to paint a clearer picture and discover the degree to which these opinions are prevalent among the categories of participants interviewed. 


\section{References}

AвC News (2019, 19 December), 'Aging South Koreans Find New Ways to Communicate Using Social Media'. Retrieved 8 July 2020 from https://abcnews.go.com/Internatio nal/aging-south-koreans-find-ways-communicate-social-media/story?id=6oo 85476/.

Ahn, Michael (2020, 23 November), 'How South Korea Flattened the Coronavirus Curve with Technology'. The Conversation. Retrieved 21 April 2021 from http:// theconversation.com/how-south-korea-flattened-the-coronavirus-curve-with -technology-136202/.

Al-Muwil, Ahlam, Weerakkody, Vishanth, El-haddadeh, Ramzi, \& Dwivedi, Yogesh (2019), 'Balancing Digital-By-Default with Inclusion: A Study of the Factors Influencing E-Inclusion in the UK'. Information Systems Frontiers, 21(3), 635-659.

Aricat, Rajiv George (2015), 'Mobile/Social Media Use for Political Purposes among Migrant Laborers in Singapore'. Journal of Information Technology \& Politics, 12(1), $18-36$.

Attewell, Paul (2001), 'Comment: The First and Second Digital Divides'. Sociology of Education, 74(3), 252-259.

Banaji, Shakuntala \& Buckingham, David (2013), The Civic Web. Cambridge: MIT Press. Bernal, Victoria (2006), 'Diaspora, Cyberspace and Political Imagination: The Eritrean Diaspora Online'. Global Networks, 6(2), 161-179.

Bertot, John C., Jaeger, Paul T., \& Grimes, Justin M. (2010), 'Using ICTs to Create a Culture of Transparency: E-Government and Social Media as Openness and Anti-Corruption Tools for Societies'. Government Information Quarterly, 27(3), 264-271.

Boulianne, Shelley, Koc-Michalska, Karolina, \& Bimber, Bruce (2020), 'Mobilizing Media: Comparing TV and Social Media Effects on Protest Mobilization'. Information, Communication \& Society, 23(5), 642-664.

Cellan-Jones, Rory (2020), 'Tech Tent: Can We Learn about Coronavirus-Tracing from South Korea?'. BBC News. Retrieved 23 November 2020 from https://www.bbc .co.uk/news/technology-52681464/.

Choe, Sang Hun (2015), 'Kim Young-Sam, South Korean President Who Opposed Military, Dies at 87'. New York Times. Retrieved 28 February 2021 from https://www .nytimes.com/2015/11/22/world/asia/kim-young-sam-former-president-of-south -korea-dies-at-87.html.

Chung, Choong Sik \& Kim, Sung Bou (2019), 'A Comparative Study of Digital Government Policies, Focusing on E-Government Acts in Korea and the United States'. Electronics, 8(11), 1362, 1-19.

Chung, Erin Aeran (2010), 'Workers or Residents? Diverging Patterns of Immigrant Incorporation in Korea and Japan'. Pacific Affairs, 83(4), 675-696. 
Chung, Erin Aeran \& Kim, Daisy (2012), 'Citizenship and Marriage in a Globalizing World: Multicultural Families and Monocultural Nationality Laws in Korea and Japan'. Indiana Journal of Global Legal Studies, (1), 195-219.

CPI (Centre for Public Impact) (2016), 'Building World-Beating e-Government in South Korea'. Retrieved 29 November 2020 from https://www.centreforpublicimpact.org/ case-study/building-a-world-leading-e-government/.

Creswell, John W., Hanson, William E., Clark Plano, Vicki L., \& Morales, Alejandro (2007), 'Qualitative Research Designs: Selection and Implementation'. Counseling Psychologist, 35(2), 236-264.

DeWind, Josh, Kim, Eun Mee, Skeldon, Ronald, \& Yoon, In Jin (2012), 'Korean Development and Migration'. Journal of Ethnic \& Migration Studies, 38(3), 371-388. Ebbers, Wolfgang E., Jansen, Marloes G.M., \& van Deursen, Alexander J.A.M. (2016), 'Impact of the Digital Divide on E-Government: Expanding from Channel Choice to Channel Usage'. Government Information Quarterly, 33(4), 685-692.

Eom, Han Jin (2008), 'The Segmentation of Korean Immigration Discourse'. Asia Yeon-gu [Asia Research]. Retrieved 1 February 2017 from http://www.dbpia.co.kr.

Fendos, Justin (2020), 'How Surveillance Technology Powered South Korea's COVID-19 Response'. Brookings. Retrieved 23 November 2020 from https://www .brookings.edu/techstream/how-surveillance-technology-powered-south-koreas -covid-19-response/.

Garcia-Garcia, Luz Maria, \& Gil-Garcia, J. Ramon (2018), 'Enacting Digital Government Services for Noncitizens: The Case of Migration Services'. In: Saeed, S., Ramayah, T. \& Mahmood, Z. (Eds.), User Centric E-Government: Challenges and Opportunities, Integrated Series in Information Systems. Cham: Springer International, pp. 167-182. Gibson, Rachel, Römmele, Andrea, \& Ward, Steven J. (2004), Electronic Democracy: Mobilisation, Organisation and Participation via New ICTs. London: Routledge.

Goggin, Gerard (2016), 'Disability and Digital Inequalities: Rethinking Digital Divides with Disability Theory'. In: Ragnedda, M. \& Muschert, G.W. (Eds.), Theorizing Digital Divides. New York: Routledge. Retrieved 13 July 2020 from https://ses.library.usyd .edu.au/handle/2123/15844/.

GOV.KR (2020), 'About GOV.KR'. Retrieved 29 November 2020 from https://www.gov .kr/portal/govEng/.

Hacker, Kenneth L. \& van Dijk, Jan (200o), Digital Democracy: Issues of Theory and Practice. Newbury Park: SAGE.

Halchin, L. Elaine (2002), 'Electronic Government in the Age of Terrorism'. Government Information Quarterly, 19(3), 243-254.

Hernandez, Kevin \& Roberts, Tony (2018), 'Leaving No One Behind in a Digital World'. Digital and Technology Cluster at the Institute of Development Studies. Retrieved 13 July 2020 from https://opendocs.ids.ac.uk/opendocs/handle/20.500 $.12413 / 14147 /$. 
Hirzalla, Fadi, Zoonen, Liesbet van, \& Ridder, Jan de. (2011), Internet Use and Political Participation: Reflections on the Mobilization/Normalization Controversy. The Information Society, 27(1), 1-15.

Ho, Alfred Tat-Kei (2002), 'Reinventing Local Governments and the E-Government Initiative'. Public Administration Review, 62(4), 434-444.

Iyer, Lakshmi S., Singh, Rahul, Salam, Al F., \& D’Aubeterre, Fergle (2006), 'Knowledge Management for Government-to-Government ( $\left.\mathrm{G}_{2} \mathrm{G}\right)$ Process Coordination'. Electronic Government, an International Journal, 3(1), 18-35.

Janssen, Davy \& Kies, Raphaël (2005), 'Online Forums and Deliberative Democracy'. Acta Politica, 40(3), 317-335.

Jennings, Nancy Ann (2000) 'Across the Digital Divide: Children, Families, and Schools in the Information Society'. PhD diss., University of Texas, Austin. Retrieved 18 December 2019 from https://www.learntechlib.org/p/115652/.

Jho, Whasun (2014), Building Telecom Markets: Evolution of Governance in the Korean Mobile Telecommunication Market. New York: Springer.

John, Jojin V. (2016), 'Globalization, National Identity and Foreign Policy: Understanding "Global Korea". Copenhagen Journal of Asian Studies, 33(2), 38-57.

Karippacheril, Tina George, Kim, Soonhee, Beschel, Robert P., \& Choi, Changyong (Eds.) (2016), 'Bringing Government into the 21st Century: The Korean Digital Governance Experience'. Directions in Development, Public Sector Governance. World Bank. Retrieved 15 September 2020 from https://elibrary.worldbank.org/doi/ abs/10.1596/978-1-4648-0881-4/.

Kersting, Norbert \& Baldersheim, Harald (2004), Electronic Voting and Democracy: A Comparative Analysis. London: Palgrave.

Kim, Hyein Amber (2020). 'Understanding "Koreanness”: Racial Stratification and Colorism in Korea and Implications for Korean Multicultural Education'. International Journal of Multicultural Education, 22(1), 76-97.

Kim, Nam Kook (2014), 'Multicultural Challenges in Korea: The Current Stage and a Prospect'. International Migration, 52(2), 100-121.

Kim, Ran (2019), 'Rethinking Open Data in E-Government in Korea: An Analysis of the Utilization Gap'. Korean Social Science Journal, 46(1), 57-75.

Kim, Sookyung (2015), 'Soft Talk, Hard Realities: Multiculturalism as the South Korean Government's Decoupled Response to International Migration'. Asian and Pacific Migration Journal, 24(1), 51-78.

Kim, Soonhee \& Lee, Jooho (2012), 'E-Participation, Transparency, and Trust in Local Government'. Public Administration Review, 72(6), 819-828.

Kim, Sung-Bou (2019), 'Political Engagement of Social Media Users in Korea'. Korea Observer, 5 O(4), 587-618.

Kim, Yoon Shik (2009), 'International Immigration, Labor Policy Research on Immigration - In the case of United States, Germany, Japan, South Korea'.Journal of Diaspora Studies, 3(1), 31-52. 
Kim, Young Kyun \& Joshi, Kailash (2016), 'South Korea's e-Government Initiatives: Export of Established Systems and Development of m-Government Systems'. Journal of Information Technology Case and Application Research, 18(2), 67-71.

Knox, Colin \& Janenova, Saltanat (2019), 'Public Management Reforms: One-Stop Shops to Digital Government'. In: Oxford Research Encyclopedia of Politics. Retrieved 4 September 2019 from https://oxfordre.com/view/10.1093/acrefore/ 9780190228637.001.00o1/acrefore-9780190228637-e-629/.

Korea Immigration Service (2019), 'Statistics on Immigration'. Retrieved 25 November 2020 from http://viewer.moj.go.kr/skin/doc.html?rs=/result/bbs/227 $\& f n=t e m p \_1581918117248100 /$.

Korea Internet \& Security Agency (2017), 'Survey on the Internet Usage Summary Report'. Retrieved 25 November 2020 from https://www.kisa.or.kr/eng/usefulre port/surveyReport_View.jsp?mode=view\&p_No=4\&b_No=262\&d_No=81.

Kostat (2019), 'International Migration Statistics in 2019'. Statistics Korea Population and Household. Retrieved 23 February 2021 from http://kostat.go.kr/portal/eng/ pressReleases $/ 8 / 5 /$ index.board? bmode $=$ read $\& b S e q=\& a S e q=384167 \&$ pageNo $=1 \&$ ro $w$ Num $=10 \&$ navCount $=10 \&$ currPg $=\&$ searchInfo= $=$ sTarget $=$ title \&sTxt $=/$.

Kraemer, Kenneth L., Dedrick, Jason, \& Sharma, Prakul (2009), 'One Laptop per Child: Vision vs. Reality'. Communications of the ACM, $5^{2(6), 66-73 . ~}$

Kvasny, Lynette \& Keil, Mark (2006), 'The Challenges of Redressing the Digital Divide: A Tale of Two US Cities'. Information Systems Journal, 16(1), 23-53.

Layne, Karen \& Lee, Jung Woo (2001), 'Developing Fully Functional E-Government: A Four Stage Model'. Government Information Quarterly, 18(2), 122-136.

Lee, Hyangsoo, Lee, Seong-Hoon, \& Choi, Jeong-A (2016), 'A Study for Multicultural Families as Digital Poverty: Focusing on Target Changes of the Digital Divide Survey for Multicultural Families'. Journal of Digital Convergence, 14(6), 1-7.

Lee, Kwang Taek (2014), 'The Legal Protection of Migrant Workers in Korea'. Retrieved 19 July 2021 from http://islssl.org/wp-content/uploads/2014/12/Lee_2O14 _Asian_Conf.pdf.

Lee, Kye Woo (2016) 'The Role of Aid in Korea's Development'. Korea's Economy, 7-25. Limb, Jae-un (2015), 'E-Gov't Exports Estimated at over \$314 Mil'. Korea.Net. Retrieved 10 April 2017 from http://www.korea.net/NewsFocus/policies/view ?articleId=129140/.

Loukis, Euripides, Dimopoulos, Stravros, \& Karacapilidis, Nikos (2005), 'ComputerSupported G2G Collaboration for Public Policy and Decision-Making'. Journal of Enterprise Information Management, 18(5), 602-624.

McKinsey (2019), 'Public-Sector Digitization: The Trillion-Dollar Challenge'. McKinsey. Retrieved 13 August 2019 from https://www.mckinsey.com/business-functions/ digital-mckinsey/our-insights/public-sector-digitization-the-trillion-dollar -challenge/. 
Min, Seong-Jae (2010), 'From the Digital Divide to the Democratic Divide: Internet Skills, Political Interest, and the Second-Level Digital Divide in Political Internet Use'. Journal of Information Technology \& Politics, 7(1), 22-35.

OECD (2002), 'OECD Glossary of Statistical Terms: Digital Divide Definition'. Retrieved 13 July 2020 from https://stats.oecd.org/glossary/detail.asp?ID=4719/.

Ramalingam, Ben \& Hernandez, Kevin (2016), 'The Multiple Forms of Digital Inequality'. In: UNEsco World Social Science Report, 2016: Challenging Inequalities; Pathways to a Just World. Paris: UNE Sco, pp. 68-69.

Ramirez, Elaine (2017), 'Nearly 100\% of Households in South Korea Now Have Internet Access, Thanks to Seniors'. Forbes. Retrieved 15 May 2017 from http://www.forbes .com/sites/elaineramirez/2017/o1/31/nearly-10o-of-households-in-south-korea -now-have-internet-access-thanks-to-seniors/.

Robinson, Michael Edson (2007). Korea's twentieth-century odyssey: A short history. Honolulu: University of Hawaii Press.

Rowsell, Jennifer, Morrell, Ernest, \& Alvermann, Donna E. (2017), 'Confronting the Digital Divide: Debunking Brave New World Discourses'. Reading Teacher, 71(2), 157-165.

Sangki, Jin (2018), 'Vision of Future E-Government via New e-Government Maturity Model: Based on Korea's e-Government Practices'. Telecommunications Policy, 42(10), 86o-871.

Schneider, Florian (2018). China's Digital Nationalism. Oxford: Oxford University Press. Silcock, R. (2001), 'What Is E-Government'. Parliamentary Affairs, 54(1), 88-101.

Smith, Dorothy E. (2005), Institutional Ethnography: A Sociology for People. Lanham: Rowman Altamira.

Statista (2021a), 'Global Internet Penetration Rate as of April 2021, by Region'. Retrieved 18 July 2021 from https://www.statista.com/statistics/269329/penetration -rate-of-the-internet-by-region/.

Statista (2021b), 'Internet Penetration Rate in Japan from 2000 to 2019'. Retrieved 18 July 2021 from https://www.statista.com/statistics/255857/internet-penetration -in-japan/.

Statista (2021c), 'Internet Usage in South Korea - Statistics \& Facts'. Retrieved 18July 2021 from https://www.statista.com/topics/223o/internet-usage-in-south-korea/.

Star, Susan Leigh \& Ruhleder, Karen (1996), 'Steps Toward an Ecology of Infrastructure: Design and Access for Large Information Spaces'. Information Systems Research, $7(1), 111-134$.

UNDESA (2020a), 'EGOVKB | United Nations > Data > Country Information'. Retrieved 25 November 2020 from https://publicadministration.un.org/egovkb/ en-us/Data/Country-Information/id/138-Republic-of-Korea/dataYear/2020/. 
Undesa (2020b), 'Digital Government in the Decade of Action for Sustainable Development'. Unite Nations E-Government Survey 2020. Retrieved 19 July 2021 from https://publicadministration.un.org/egovkb/en-us/Reports/UN-E -Government-Survey-2020.

United Nations (2018), 'United Nations e-Government Survey 2018: Gearing e-Government to Support Transformation Towards Sustainable and Resilient Societies'. Retrieved 19 July 2021 from https://www.unescap.org/resources/e -government-survey-2018-gearing-e-government-support-transformation-towards -sustainable.

van Deursen, Alexander \& van Dijk, Jan A.G.M. (2014), 'The Digital Divide Shifts to Differences in Usage'. New Media \& Society, 16(3), 507-526.

van Dijk, Jan A.G.M. (200o), 'Models of Democracy and Concepts of Communication'. In: Hacker, Kenneth L. \& van Dijk, Jan (200o), Digital Democracy, Issues of Theory and Practice. Newbury Park: SAgE Publications (pp. 30-53).

Warkentin, Merrill, Gefen, David, Pavlou, Paul A., \& Rose, Gregory M. (2002), 'Encouraging Citizen Adoption of E-Government by Building Trust'. Electronic Markets, 12(3), 157-162.

Won, Il Hee (2002), 'Official Launch of E-Government ... Opening of Online Civil Service'. sBs News. Retrieved 6 February 2017 from http://news.sbs.co.kr/news/end Page.do?news_id=No311320553/.

World Bank (2019), 'Individuals Using the Internet (\% of Population)'. Retrieved 25 November 2020 from https://data.worldbank.org/indicator/IT.NET.USER.ZS ?most_recent_value_desc=true/.

Zúñiga, Homero Gil de, Veenstra, Aaron, Vraga, Emily, \& Shah, Dhavan (2010), 'Digital Democracy: Reimagining Pathways to Political Participation'.Journal of Information Technology \& Politics, 7(1), 36-51. 